\title{
Reaction of College Teachers about HEART Training Program in Khyber Pakhtunkhwa
}

\author{
* Iftikhar Ali, PhD Scholar (Corresponding Author) \\ ** Dr. Rahim Khan, Assistant Professor
}

\begin{abstract}
The impact of training is always very valuable and positive on the performances of employees in every organization. The main objective of this study was to know the reaction of the college professors who received training from the HEART training academy. Total (1320) professors of different colleges completed the training up to June 2018 from HEART. The study was restricted to districts Charsadda, Mardan, Nowshera, Peshawar, and Swabi. In the above mention districts, the trained college teachers were three hundred (320) and the sample size was one hundred and seventyfive (175). The Kirkpatrick's Evaluation Model was used. The nature of the study was a survey and a five-point Likert Scale questionnaire was used for the collection of data. The data were collected from college teachers trained by HEART. The collected data were analyzed through SPSS version 20. The analysis showed that the reaction of trained teachers was very positive about the training.
\end{abstract}

Keywords: Training, HEART, Reactions, Kirkpatrick's Evaluation Model

\section{Introduction}

Citizens of a state play a key role in the development of a nation. There is an indispensable relationship between the well-developed citizens and their education. For this purpose, Ibrahim (1997) refers to the fact, "the development of a nation's education depends upon the development of their teachers." If someone turns a deaf ear to the professional aspect of a teacher, it is understood that the whole nation is overlooked. The ongoing trend of professional education of teachers needs evaluation to pave a road of betterment for good quality education (UNESCO, 2008). One cannot expect standard education in the absence of effective teachers, and it is a fact that one can revolutionize the education system by putting teachers into effective professional trainings. Bearing in mind the above object, HEART stated to train college teachers. For the time being, solely institution naming "Higher Education Academy for Research and Training" has assigned to itself to impart in-service training to college teachers (lecturers, assistant professors, and associate professors) declared mandatory for their promotion. All over the world, a model of instructional process has gone through s number of changes resulting in teacher evaluation and certification mechanism to properly assess the professional caliber of teachers. This is the reason; HEART provides training programs to appraise the training program effectively.

The researcher has resorted to the $1^{\text {st }}$ level of the Kirkpatrick model which is thought to be a yardstick for evaluating training outcomes. A brief sketch of the Kirkpatrick Model is as under;

Kirkpatrick a professor at the University of Wisconsin has divided his model into four levels. Here the focus and emphasis is on level-1 that is: "Reaction".

Evaluation Levels (Kirkpatrick, 1998)

\begin{tabular}{lll}
\hline $\begin{array}{l}\text { Advanced level } \\
\text { of evaluation }\end{array}$ & Level 4: Results & $\begin{array}{l}\text { Did the behavioral changes positively affect the } \\
\text { organization? }\end{array}$ \\
Level 3: Behavior & $\begin{array}{l}\text { Did the participants hold their behavior to some change } \\
\text { that was imbibed in the earlier program? }\end{array}$ \\
\hline $\begin{array}{l}\text { Basic level of } \\
\text { Levaluation }\end{array}$ & $\begin{array}{l}\text { Lhat changes happened to skills, knowledge, or } \\
\text { disposition have change? Up to what extent? }\end{array}$ \\
& $\begin{array}{l}\text { Did the participants look happy? } \\
\text { Where do they want to for after having the program } \\
\text { learned? }\end{array}$
\end{tabular}

The study will benefit the college teachers, principals of colleges, higher education academy of training and research, policymakers, and higher education department.

* Qurtaba University of Science and Information Technology, Peshawar Email: iftikhar1077@gmail.com

** Qurtaba University of Science and Information Technology, Peshawar Email: dr.rahim43@ gmail.com 


\section{Objective of the Study}

a) To find out the reaction of college teachers about the HEART training program for college teachers.

\section{Hypothesis of the Study}

$\mathrm{Ho}^{1}$ : There is no significant effect of trained college teacher's reaction on the teachers training program of HEART.

\section{Literature Review}

According to Perron (1991), "The in-service training is to improve teachers' proficiency. Professional development is of utmost necessary for result-oriented give and take, as stated by (Cohen \& Hill, 1998). In the view of Darling and Hammond (2000) professionally skilled teacher is of key importance for quality education. In this respect, Scot et al. (2007) concluded that not only teacher training is important but continuous and updating evaluation is also inevitable. A high-quality skilled teacher is the cry of the day, stated by Goldhaber and Anthoney, (2004). In the same way, the teaching-learning process is incomplete in the absence of trained teachers, therefore, quality education rests on quality teacher as stated by Frome, Lasater, and Cooney, (2005).

As well as Lathan and Gitomer (1999) are concerned they state that one cannot underestimates the role of developing a teacher and its effect on classroom teaching. It has been observed by Ballou and Podgursky (2000) that several strategies are needed while training teachers. The positive and pragmatic approach of trainees highly matter during training, as highlighted by (Holtzman \& Galton 2007). Similarly, trainee teachers whose residential areas and educational background are different, also play a key role in the teaching and learning process (Wenligsky, 2000; Clotfelter, Ladd \& Vigdor, 2006).

Teacher training renders to channelize the pedagogical skills of trainee teachers' in effective way via different teaching methods for training carry a considerable weight in instruction (American Federation of Teacher, 2000). Coggshall (2007) considers teacher training programs so fruitful that it improves both the social and educational skills of an instructor. An effective teacher always aims to improve their teaching skills, asserted by Fullan and Stiegelbauer (1991). Those who are new-comers and those in service, for both a peaceful and learning environment must be provided so that they may fully furnish themselves with new training methods (Adams, 1998, McNergney, Robert \& Herbert, 2001). It is thought, teacher training for pre-service teachers is less effective because learning skills and techniques go through several changes over time (Shah, \& Masrur, 2011).

As time passes on, educational skills, theories, and approaches also adapt to new challenges, stated by (Demirtas, 2010). Many researchers on education state that quality of education is subject to the high caliber of teaching staff and their professional education because the teachers with high caliber cast a greater impact on the development of the teaching and learning process (Borko, 2004; Garet, Porter, Desimone, Birman \&Yoon 2001).

The main purpose of in-service training is to ascertain better performance of both teachers and students, by Hewson (2007). Balta (2014) says that there exists an unbreakable relationship between professional expertise and his/her partaking in in-service training programs. It is also recorded that students can get high achievement only if they are provided with trained teachers (Damar, 1996). According to (Lock, 1984) $1^{\text {st }}$ program bear a lot of advantages, and he has stated that an in-service training program is highly lucrative for both teachers and their students. Training is such a worthy tool that renders teachers greatly to build up themselves. An instructor must have sound knowledge of how to teach effectively, stated by (Alawiye \& William 2001). Teacher training assumes a lot of time. In the view of Hussain (2003) both training and good performance go hand in hand, further he advises avoid using A-V Aids like multimedia, computer etc. but recourse to charts and boards and lecture method which is quite suitable for the setup of our country.

Cao and Neitfield (2005) declare that the performance of teachers turned out too good and satisfactory when they cast a second glance over their strategies and planning, leading them to take help and guidelines from curriculum, during their education. The follow-up programs are highly necessary to assess that trainings help in the development of teaching methods. The non-stop assessment of teachers is unavoidable for it helps to find out the deficiencies in the teaching-learning process (UNESCO, 2006).

Training is provided to polish the teacher to manage their classroom, to groom their skills, and pave a path for better and effective result-oriented teaching as stated by Moore (2004). According 
to Farooq and Shehzadi (2006), good teachers have a full grip over their subject and the required skills to deliver it properly. Topno (2012), asserted that teacher is key for all activities of an organization. Sanders (2011), comments that in the past training was known as an aimless activity. But now it recognizes as an investment activity.

Byrne (1999), agrees with Janzeb and Bashir (2012), that in the present era most human organizations approaching modernization. All these possible if and only if to equip their employees with updated skills and knowledge.

Khan (2004) stated that the performances of teachers have not moved ahead at the pre-service stage. According to Diem (2002) result-oriented training manifests itself in the behavior of students. Wong (2004) finds that training brought positive changes in learner's ability which means that the programs were successful. In the view of Guskey (2000), professional training renders to improve the give and take, so it is necessary to get such training programs to improve our teaching-learning process. We have mainly two reasons that back up the importance of assessments. Firstly, teacher training programs facilitate teachers to come up with any situation anywhere. Secondly, our world is passing through several changes; therefore, it is necessary to make ready our teachers for those changes. Bezzina (2006) says that in-service training carries on utmost importance for it boost the overall caliber of a teacher in terms of skills, knowledge, and professional development. Teacher training enables the teacher to instruct their students effectively. We have thrown light on the fact that there is no need for pre-service training for the college staff of KPK, Pakistan. Keeping in view inservice training multiplies the capabilities of teachers to a greater extent. In this regard, HEART is the sole institute of the public sector to provide training to college teachers. There are two types of training namely pre-service training and in-service training.

\section{Per-Service Training}

Teacher's development is highly connected to the advancement of the nation, and the teacher's development closely attached to the well-developed training system, proper training and updated subject knowledge is important for the professional development (National Educational Policy, 2010). Most of the researchers agreed that efficient and effective teachers are essential for the attainment of national goals, so, training is a vital tool for the profession of teaching. The process of developing human ability and capacity is known as training. Well trained teachers can grip teaching skills need them in their job (Nietfeld \& Cao, 2003). But unlucky the phase of pre-service training is missing for the college teachers in Khyber Pakhtunkhwa. So the whole focus is on in-service training.

\section{In-Service Training}

When employees join the service and after the organization intends to improve the capacity and skills of them, then such type of training is called in-service training. The in-service training is also a continuous professional development (CPD. The goal attainment is highly linked with the well-trained employees. An organization does not achieve success unless and until to give continuous training to their employees (Arguis \& Kraiger, 2009). As the demands of society increase day by day which need regular and updated skills and knowledge as asserted by (Niazi, 2011).

As already stated that college teachers are directly recruited by the public service commission, and without getting the training they join their duty, so in this situation, the in-service training is very important for them.

In 2016, the government of Khyber Pakhtunkhwa established a training and research institute naming HEART to improve the professional skills of public sector college teachers of the province.

\section{Research Methodology \\ Research Design}

Quantitative, qualitative, and mixed are the main types of methodology of research. Words are used in qualitative and numbers are used in quantitative when a researcher used words as well as numbers than its turns mixed method of research (Creswell, 2013). The study was descriptive in nature. The use of the quantitative method increased after 1950. The views of the trained college professors was found out in the present study about the HEART training program of Khyber Pakhtunkhwa, Pakistan Sample and Sample Techniques

Total (1320) professors of different colleges completed the training up to June 2018 from HEART. The study was restricted to districts Charsadda, Mardan, Nowshera, Peshawar, and Swabi because of the difficulty of money and resources. In the above five districts, the target population was (320) 
teachers of college and (175) trained college teachers of HEART training were selected as a sample using random sampling techniques.

\section{Data Collection Tools}

The permission letter was issued by the co-ordination office Qurtuba University Peshawar. The data were randomly collected through questionnaire from the trained college teachers of districts Charsadda, Mardan, Nowshera, Peshawar, and Swabi. The reliability of the research instrument was checked through pilot testing. Thirty-five filled questionnaires from college teachers each from the five districts which became one hundred, seventy-five in total through visit personally. The data collected through questionnaires were summarized and the statistical tools of percentage and chisquare were used for analysis. Version 20 of SPSS was used for data analysis. The software analyzed the entered data by chi-square and percentage.

From the analysis of the data, it is clear that the null hypothesis "There is no significant effect of trained college teacher's reaction on teachers training program of HEART" is rejected because the reaction of college teachers are very positive about HEART training program.

\begin{tabular}{|c|c|c|c|c|c|c|c|c|c|}
\hline \multirow{2}{*}{ SNO } & \multicolumn{2}{|l|}{ Items } & \multirow{2}{*}{$\begin{array}{l}\text { SA } \\
\text { Lev } 1\end{array}$} & & \multirow{2}{*}{$\begin{array}{l}\text { UD } \\
\text { Lev3 }\end{array}$} & \multirow{2}{*}{$\begin{array}{l}\text { DA } \\
\text { Lev4 }\end{array}$} & \multirow{2}{*}{$\begin{array}{l}\text { SDA } \\
\text { Lev5 }\end{array}$} & \multirow{2}{*}{$\stackrel{\substack{3 \\
?}}{2}$} & \multirow{2}{*}{$\chi^{2}$} \\
\hline & & & & & & & & & \\
\hline \multirow[t]{2}{*}{1} & \multirow{2}{*}{$\begin{array}{l}\text { I enjoyed the training } \\
\text { arranged at HEART for } \\
\text { college teachers. }\end{array}$} & $f$ & 102 & 64 & 04 & 03 & 02 & 175 & \multirow[t]{2}{*}{240.114} \\
\hline & & $\%$ & 58.3 & 36.6 & 2.3 & 1.7 & 1.1 & 100 & \\
\hline \multirow[t]{2}{*}{2} & The Seminar Room, Staff, & $f$ & 79 & 89 & 02 & 03 & 02 & 175 & \multirow[t]{2}{*}{230.114} \\
\hline & $\begin{array}{l}\text { Support, refreshment, and } \\
\text { basic facilities were good } \\
\text { enough for training. }\end{array}$ & $\%$ & 45.1 & 51.0 & 1.1 & 1.7 & 1.1 & 100 & \\
\hline \multirow[t]{2}{*}{3} & \multirow{2}{*}{$\begin{array}{l}\text { The objectives of the training } \\
\text { were clearly defined to me. }\end{array}$} & $f$ & 48 & 119 & 02 & 02 & 04 & 175 & \multirow[t]{2}{*}{296.114} \\
\hline & & $\%$ & 27.4 & 68.0 & 1.1 & 1.1 & 2.4 & 100 & \\
\hline \multirow[t]{2}{*}{4} & \multirow{2}{*}{$\begin{array}{l}\text { The training environment } \\
\text { was conducive for learning. }\end{array}$} & $f$ & 53 & 110 & 06 & 03 & 03 & 175 & \multirow[t]{2}{*}{252.514} \\
\hline & & $\%$ & 30.5 & 62.7 & 3.4 & 1.7 & 1.7 & 100 & \\
\hline \multirow[t]{2}{*}{5} & The contents taught in the & $f$ & 65 & 72 & 14 & 20 & 04 & 175 & \multirow[t]{2}{*}{111.314} \\
\hline & $\begin{array}{l}\text { HEART training are relevant } \\
\text { to the College Sector. }\end{array}$ & $\%$ & 37.1 & 41.3 & 8.0 & 11.3 & 2.3 & 100 & \\
\hline \multirow[t]{2}{*}{6} & The training is beneficial for & $f$ & 69 & 75 & 12 & 15 & 04 & 175 & \multirow[t]{2}{*}{132.743} \\
\hline & my professional career & $\%$ & 39.4 & 43.8 & 6.9 & 8.6 & 2.3 & 100 & \\
\hline \multirow[t]{2}{*}{7} & \multirow{2}{*}{$\begin{array}{l}\text { The standard of provided } \\
\text { training materials was good. }\end{array}$} & $f$ & 39 & 94 & 18 & 22 & 02 & 175 & \multirow[t]{2}{*}{144.114} \\
\hline & & $\%$ & 22.3 & 53.7 & 10.3 & 12.6 & 1.1 & 100 & \\
\hline \multirow[t]{2}{*}{8} & \multirow{2}{*}{$\begin{array}{l}\text { I am clear about what is } \\
\text { expected of me on the job as } \\
\text { a result of taking this } \\
\text { training. }\end{array}$} & $f$ & 51 & 90 & 19 & 12 & 03 & 175 & \multirow[t]{2}{*}{145.429} \\
\hline & & $\%$ & 29.1 & 51.4 & 10.9 & 6.9 & 1.7 & 100 & \\
\hline \multirow[t]{2}{*}{9} & Resource persons are & $f$ & 55 & 83 & 18 & 11 & 08 & 175 & \multirow[t]{2}{*}{122.800} \\
\hline & $\begin{array}{l}\text { knowledgeable and skilled in } \\
\text { their areas. }\end{array}$ & $\%$ & 31.4 & 47.4 & 10.3 & 6.3 & 4.6 & 100 & \\
\hline \multirow[t]{3}{*}{10} & I recommend this program to & $f$ & 75 & 78 & 06 & 12 & 04 & 175 & 165.143 \\
\hline & $\mathrm{m}$ & $\%$ & 42.9 & 44.6 & 3.4 & 6.8 & 2.3 & 100 & \\
\hline & Overall Results \% & & 36.33 & 50.01 & 5.72 & 5.88 & 2.06 & 100 & \\
\hline
\end{tabular}

\section{Findings}

The analysis showed that the findings of the study were that the training institution of HEART provides training to the teachers of college from few years. The training center was well-furnished building all the trainees were satisfied with the arrangement and enjoyed training environment. The people involved were trainers, staff and director of the institute and the trainee were satisfied in majority. The effective measurements were taken for training by the institute and the reaction as well as views of trainees positive about the training of HEART institute. The environment of the training venue was conducive for learning and the contents were much related to the job description of college teachers. The resource persons of the training were resourceful and competent in the relevant field. 
The trainees were satisfied with all the aspects of HEART training therefore they strongly recommended HEART training programs for teachers and principals of their department.

\section{Discussion}

The training institute of HEART was established in 2016 by the KP government to provide training to the college teachers, principals, and other officials of the department. The training environment and facilities were up to the mark. The trainings were organized, planned and the materials of the training were very relevant to the job nature of college teachers. The resource persons were very competent which shows that the training institute properly validated the trainers before their selection as trainers for the training.

\section{Conclusion}

The researcher analyzed the collected data draw findings, did discussion on those findings and the conclusion was drawn from it. The study showed that all the trainees were very satisfied with their training. The findings showed that the contents were closely related to the job description of college teachers and the resource persons make them clear about all the content of the training. All the trainees fully utilized the training opportunities for their professional development and recommended the HEART for teachers, principals, and other officials of the department.

\section{Recommendations}

The findings and conclusion of the study showed that the reaction of the majority of the trainees were positive about the Heart training. Based on the positive views of trainees about HEART training they recommended the training for all the college teachers because it would help them conduct and supervise the research of their BS students effectively and they would be able to perform their official duties inside their institute effectively.

\section{References}

Adams, T. (1998). Prospective elementary teachers' mathematics subject matter knowledge: The real number system. Journal for Research in Mathematics Education, 20, 35-48.

Aguinis H. \& Kraiger K. (2009). Benefits of Training \& Development for Individuals and Teams, Organization and Society. Annual Review of Psychology is online at Psych.anualreviews.org.

Alawiye, O. \& Williams, H. (2001). Assessment: lessons learned from a year-long undergraduate teacher education pilot program (Statistical Data), Journal of Instructional Psychology; 28 (4), 229-233.

American Federation of Teachers (2000, April). Building a profession: Strengthening Teacher preparation and induction (Report of the K-12 Teacher Education Task Force). Washington, D. C.: Author.

Ballou, D., \& Podgursky, M. (2000). Reforming teacher preparation and licensing: What is the Evidence? Teachers College Record, 102, 28-56.

Balta, N. (2014). The effect of a professional development program on physics teachers' knowledge and their students' achievement in modern physics unit. Unpublished Doctoral dissertation, Middle East Technical University, Ankara.

Bezzina, C. (2006). Views from the teachers: Beginning teacher's perceptions about their professional development. Journal of In-service Education, 32(4), 411-430

Borko, H. (2004). Professional Development and teacher learning: Mapping the terrain. Educational Researcher, 33(8), 3-15. http://dx.doi.org/10.3102/0013189X033008003

Byrne S.M. (1999). The Value of Human Resource Development to an Organization: Providing Technical Assistant to Small Manufacturing Companies. Dissertation Submitted to the faculty of the Virginia Polytechnic Institute and State University in Partial Fulfillment of the Requirement of Degree.

Cao, L. \& Nietfeld, L. J. (2005). Judgment of Learning, Monitoring Accuracy, and Student Performance in the Classroom Context. Current Issues in Education [On-line], 8 (4): http://cie.ed.asu.edu/volume8/ number4/ (retrieved on July 11, 2006).

Clotfelter, C.T., Ladd, H.F, \& Vigdor, J.L. (2006). Teacher-student matching and assessment of teacher effectiveness, (NBER working paper No. 11936). Cambridge MA, National Bureau of Economic Research pp.22-3

Coggshall, J.C. (2007). Communication framework for measuring teacher quality and effectiveness: Bringing coherence to the conversation. 
Cohen, D. K., \& Hill, H. C. (1998). Instructional policy and classroom performance: The mathematics reform in California (CPRE Research Report Series, RR-39).

Diem, K. G. (2002) Measuring the impact of educational programs, a fact sheet (New Jersey, The State University of New Jersey).

Damar, M. (1996). İlkokuma Yazma Öğretiminde Karş1laş1lan Güçlüklerle Öğretmen Nitelikleri Arasındakilliş̧ki. Unpublished master thesis, Hacettepe University, Ankara

Darling \&Hammond, D. (2000). How Teacher Education Matters? Journal of Teacher Education, 51 (3), pp.145- 155.

Demirtaş, Z. (2010). As a tool for training teachers in service, supervision. Electronic Journal of Social Sciences, 9(31), 41-52.

Farooq, M. S., \& Shahzadi, N. (2006). Effect of teachers' professional education on students' achievement in mathematics, Bulletin of Education \& Research. 28 (1), 47-55.

Frome, P., Lasater, B., Cooney, S. (2005). Well qualified teachers and high-quality teaching: are they the same? Atlanta, GA: Southern Regional Educational Board.

Fullan, M., with Stiegelbauer, S. (1991).The new meaning of educational change. New York: Teacher's College Press.

Garet, M. S., Porter, A. C., Desimone, L. M., Birman, B. F., \& Yoon, K. S. (2001).What makes professional development effective? Results from a national sample of teachers. American Educational Research Journal, 38(4), 915-945. http://dx.doi.org/10.3102/00028312 038004915 change. New York: Teacher's College Press.

Gitomer, D. H., \& Latham, A. S. (1999). The academic quality of prospective teachers: The impact of admissions and licensure testing. Princeton, NJ: Educational Testing Service.

Goldhaber, D.D., \& Anthoney, E. (2004). Can teacher quality be effectively assessed? (Working paper) Seattle, WA: Center on reinventing public education.

Government of Pakistan, Ministry of Education, (1998). National Education Policy, 1998-2010, Islamabad.

Guskey, T.R. (2000). Evaluating professional development. Thousand Oaks, CA: Corwin Press.

Hewson, P. W. (2007) Teacher Professional development in science. Handbook of research on science education. Lawrence Erlbaum Associates Publis. Matwah, New Jersey.

Holtzman and Galton, S.J. (2007). Does teacher preparation matter? Evidence about teacher certification, Teach for America, and teacher effectiveness. Education Policy Analysis Archives 13 (48).

Hussain, S. (2003). Input-output analysis of Government Colleges for Elementary Teachers in Sargodha Division. M. Phil. (Education) thesis submitted at the Department of Teacher Education, Allama Iqbal Open University- Islamabad.

Ibrahim, K.M. (1997). Tarbiat-e-Asateze: Pakistan Education Foundation, Islamabad.

Imig, C. David, \& R. Scott. (2007). Quality in Teacher Education: Seeking a Common Definitions, Handbook of Teacher Education, Springer, P. 95

Jehanzeb K. \& Bashir N. A (2013). Training \& Development Program and its Benefits to Employee and Organization: A Conceptual Study. European Journal of Business and Management, 5(2)

John W. Creswell (2013) Research Design: Qualitative, Quantitative, and Mixed Methods Approaches, SAGE Publications Ltd, $4^{\text {th }}$ Edition, pp 32.

Kirkpatrick, D. L. (1998). Evaluating Training Programs: The Four Levels. San Fransisco BerrettKoehler Publisher, Inc

Khan, S. C. (2004). From Practice to Policy: Making a Difference. Report prepared for the Teachers' Resource Centre. Karachi, Pakistan.

Locke, L. F. (1984). Research on teaching teachers: where are, we now? Journal of teaching physical education, Monograph 2.

McAnarney, Robert, F. \& Herbert J.M. (2001). Foundations of Education: The Challenge of Professional Practice. Boston: Allyn and Bacon

Moore, A. (2004). The good teacher: dominant discourses in teaching and teacher education (London, Routledge Palmer).

Niazi A.S. (2011). Training \& Development Strategy and Its Role in Organizational Performance. Journal of Public Administration and Governance, 1(2), 2161-7104. 
Nietfeld, J. L. \& Cao, L. (2003, June 19) Examining instructional strategies that promote pre-service teachers' teaching efficacy. Current Issues in Education [On-line], 6(11). Available online at: http://cie.ed.asu.edu/volume6/number11/ (accessed on July 5, 2006)

Perron, M. (1991). Vers UN continuum de Formation des Enseignants: Elements D' Analyse. Rechercheet Formation, 10, 137-152.

Saiti, A. (2006). In-service training for teachers who work in Full Day schools- Evidence from Greece. European Journal of Teacher Education, 29(4), 455-470.

Sanders T. (2011). Hotel Front Office Training: Turning Expenses into Investment. University of Nevada Las Vegas, Thesis/Dissertation/Professional Paper Capstone, 7-1

Shah.S.M \& Masrur.R. (2011). Impact of Micro Teaching Skills on The Performance of Primary School Teachers. Gomal University Journal of Research 27.p-15-29.

Topno H. (2012). Evaluation of Training \& Development: An analysis of Various Training Models. Journal of Business Management, 5(2), 16-22.

UNESCO (2006). Situation analysis of teacher education in Pakistan: Towards a strategic framework for teacher education and professional development (Islamabad, UNESCO).

UNESCO (2008). Status of teacher education in the Asia Pacific region. International Reading Association Bangkok http://www.unescobkk.org/education/apeid/programme. Accessed on July 5, 2009.

UNESCO (2008). Status of teacher education in the Asia Pacific region. International Reading Association Bangkok http://www.unescobkk.org/education/apeid/programme. Accessed on July 5, 2009.

Wenglinsky, H. (2000). Teaching the teachers: Different settings, different results. Princeton, NJ: Educational Testing Service.

Wong, P (2004). The PD of school principals: insight from evaluating a program in Hong Kong. School Leadership and Management, 24 (2), 139-162. 